\title{
Dissemination of productivity enhancement technologies in pigeonpea through frontline demonstrations
}

\author{
K.R. Shreenivasa* and T.S. Sukanya \\ Krishi Vigyan Kendra, Konehally, Tumkur (Karnataka) India \\ (Email: shreenikr@rediffmail.com)
}

\begin{abstract}
The demontration was carried out during Kharif 2016 in three villages of Tumkur district where 25 demonstrations on Pigeonpea crop were carried out in an area of 10 ha by the active participation of farmers with the objective to demonstrate the improved technologies in pigeonpea to exploit production potential. The improved technologies consisted of use of improved wilt resistant variety, seed treatment with Rhizobium culture, soil application Trichoderma and phosphate solubilising bacteria, balanced fertilizer application and integrated pest management. Frontline demonstrations (FLDs) recorded higher yield as compared to farmers' local practice. The improved technology recorded higher yield of 10.5 q/ha compared to 8.25 q/ha in farmers' local practice. In spite of increase in yield, technological gap, extension gap existed. The improved technology gave higher gross return, net return with higher benefit/cost ratio than farmers' practices.
\end{abstract}

Key Words : Pigeonpea, FLD, Improved technologies

View Point Article : Shreenivasa, K.R. and Sukanya, T.S. (2019). Dissemination of productivity enhancement technologies in pigeonpea through frontline demonstrations. Internat. J. agric. Sci., 15 (1) : 98-101, DOI:10.15740/HAS/IJAS/15.1/98-101. Copyright@ 2019: Hind Agri-Horticultural Society.

Article History : Received : 26.07.2018; Revised : 30.11.2018; Accepted : 06.12.2018

\footnotetext{
* Author for correspondence:
} 